\title{
A PersistênCia de LuKács
}

\author{
LUKÁCS, György. \\ Prolegômenos para uma ontologia do ser social. \\ São Paulo: Boitempo, 2010.
}

\section{POR}

\section{Paulo Rodrigues Gajanigo ${ }^{1}$}

$\mathrm{P}$ rolegômenos, apesar de ter sido escrito há cerca de 40 anos, é um livro atual e pode ser considerado um dos livros marxistas mais importantes lançados entanto, o livro chega ao Brasil com um estranho ar de ineditismo. Trata-se de uma reorganização expositiva e uma introdução, realizada pelo próprio György Lukács, ao manuscrito chamado Por uma Ontologia do Ser Social (sem tradução completa publicada em português). Lukács submeteu o manuscrito a um grupo de alunos (dentre eles os famosos Agnes Heller e Ferenc Feher) e, após ouvir suas críticas, escreveu o texto que, ora, resenhamos.

A força desse escrito está em encarar de maneira rigorosa a tarefa de renovação do marxismo por meio de dois veios: o resgate do pensamento marxiano; e a reflexão sobre a especificidade da sociedade contemporânea. No primeiro aspecto, Lukács se esforçou em fazer uma profunda crítica ao stalinismo, especialmente, à forma como este deturpou o pensamento marxista e marxiano. Para tanto, partiu da unidade da obra marxiana. Lukács negou decididamente a separação radical entre as obras do jovem e do velho Marx. Seu esforço esteve em demonstrar que o método empreendido por Marx para desvelar a sociedade

\footnotetext{
${ }^{1}$ Graduado em Ciências Sociais e Mestre em Antropologia Social pela Unicamp. Doutorando em Ciências Sociais pela UERJ. gajanigo@gmail.com
} 
capitalista se fundamenta numa ontologia própria, que foi esclarecida nos seus trabalhos de juventude.

Lukács caracterizou a ontologia marxista como aquela que considera todo ser como histórico, seja ele inorgânico, orgânico ou social. Como afirmou Marx, todo ser só é objetivo se tem relação com outro ser. Dessa forma, o ser está sempre ligado aos complexos de seres e, portanto, está inserido em processos irreversíveis. 0 método de compreensão dessa historicidade de todos os tipos de seres seria, portanto, a dialética. No entanto, o fato universal da historicidade não exclui as especificidades de cada tipo de ser que são decisivas para sua compreensão. Só o ser social age teleologicamente, idealiza antes de agir e, portanto, pode criar formas novas nos seres. Por isso, o trabalho, em sentido antropológico, tem o papel central na ontologia apresentada por Lukács, já que nele teríamos o salto qualitativo de ser orgânico para ser social, com a consequente aparição de categorias próprias do ser social, tais como: teleologia, liberdade, valor e alternativa.

Essa perspectiva levou o autor a criticar a concepção da dialética de Friedrich Engels, que igualou as categorias da dialética nos seres exclusivos da natureza e os seres sociais, favorecendo a deturpação stalinista com a criação de uma lógica dialética abstrata. Lukács se opôs a essa visão afirmando o monismo ontológico sem desconsiderar que os desenvolvimentos e desdobramentos dos seres (se são orgânicos, sociais...) instauram legalidades próprias e exigem do conhecimento sobre eles categorias próprias.

Por tomar essa posição, Lukács esteve em condição de criticar o determinismo econômico imperante no marxismo sem abrir mão de afirmar a prioridade ontológica da produção da vida, ou seja, de que toda forma ideológica é uma resposta a questões colocadas pelo modo específico da produção social da vida. Renovar o marxismo, para Lukács, passa por livrar Marx das inúmeras deturpações.

De outro lado, encontramos no Prolegômenos a visão de Lukács sobre questões sociais contemporâneas. Nesse sentido, o filósofo húngaro faz a crítica ao stalinismo não só por sua deturpação do pensamento marxista, mas também demonstra como o que se efetivou na URSS sob o stalinismo gerou formas de sociabilidade quese tornaram barreiras para alutapelaemancipação humana. Para compreender o que ocorreu tanto na URSS quanto no capitalismo contemporâneo, Lukács resgatou o polêmico conceito de alienação ou estranhamento.

Diferentemente dos outros animais, o gênero humano é efetivado por meio da criação pelos próprios homens (trabalho) das suas condições 
de existência. Dessa forma, o exemplar (ser humano concreto) não realiza 0 gênero imediatamente - 0 que se torna a condição básica para que se gere 0 estranhamento entre 0 gênero concreto humano e a vida dos exemplares. 0 enfrentamento desse estranhamento não se dá imediatamente na ação humana sobre a produção social, mas, necessariamente, parte das esferas ideais, já que se trata de um estranhamento, em princípio, entre a vida singular e o gênero. Lukács, assim, consegue criticar amplamente o stalinismo, já que este, mesmo apoiado numa economia planificada e estatizada, reproduziu as alienações, como é possível perceber na constante submissão das individualidades realizadas pelo regime.

Foi sobre as questões contemporâneas que o pensamento do último Lukács teve menos inserção nos debates acadêmicos. Nesse meio, o marxismo tem sido visto como uma teoria superada, quando não, está na condição de refugiada nas cadeiras de sociologia do trabalho e economia política. 0 incômodo causado pela posição lukacsiana é o de que o marxismo não só ajuda a compreender o que acontece no "mundo do trabalho", mas é imprescindível para se entender a esfera da cultura hoje.

No Prologômenos, e com mais detalhe na Ontologia, Lukács argumentou que aprincipal forma atual do estranhamentoéderivada do excesso de manipulação da vida (fenômeno ligado ao controle cada vez maior do Capital na esfera do consumo). A posição de Lukács é instigante por relacionar este fenômeno com a teoria marxiana da tendência a uma crescente socialização da sociedade. Aqui, ao contrário de muitos teóricos que se deparam com uma evidente complexificação da sociedade capitalista, Lukács não partiu para o ecletismo teórico, procurou, em vez, avaliar sobriamente suas consequências para a luta pela emancipação humana, demonstrando que a nova forma de exploração (a subsunção real) faz desaparecer "do movimento de trabalhadores a coincidência imediata entre a luta contra a própria exploração e luta contra as consequências do estranhamento para os homens". De forma que a "luta, evidentemente necessária contra 0 estranhamento recebe, devido à mudança econômica, um caráter sobretudo ideológico." (p. 307).

Os marxistas encontrarão nesse livro uma arma destacável no debate vigente da teoria social que, deparada com lutas que não podem ser relacionadas imediatamente com a exploração, tem afirmado, com frequência, estar perante a prova do fim das classes enquanto sujeitos históricos.

Infelizmente, os 40 anos passados da concepção do livro não foram 
suficientes para sua vulgarização. Sem dúvida, o sufocamento sofrido pelo marxismo com o stalinismo (e também com o academicismo que dividiu Marx entre o humanista e o cientista) assim como a forte corrente ideológica antimarxista que se apoiou no fim da URSS, são as determinantes principais para explicar essa debilidade. Outros pontos, mais específicos, podem ser citados, como o fato do texto ser de leitura árdua, escrito em condições precárias de saúde, e de Lukács debater, fundamentalmente, com autores considerados clássicos, sem fazer referência a autores mais recentes.

No Brasil, o pensamento do último Lukács foi trazido por poucos, mas sólidos pensadores. Leandro Konder, Carlos Nelson Coutinho, José Paulo Netto, José Chasin, entre outros. Foi uma geração que teve o papel de apontar para a relevância da obra lukacsiana. Há já uma segunda geração dedicada à sua ontologia que se divide, em traços gerais, entre um foco na exegese da obra do último Lukács e 0 debate sobre as mudanças contemporâneas no mundo do trabalho.

A profundidade e fertilidade das análises de Lukács no Prolegômenos evidenciam que todo o esforço já feito é um importante começo que deve avançar na exploração de inúmeros aspectos. Destaco em especial a reflexão de Lukács sobre as formas contemporâneas de alienação ligadas ao excesso de manipulação da vida cotidiana. 0 exame profundo desse aspecto pode contribuir para a visão marxista da cultura contemporânea. Com esta publicação, dá-se um incentivo para que uma terceira geração, mais numerosa, possa desbravar os campos hoje pouco receptivos ao marxismo bem como ajudar no seu reavivamento. 